\title{
Veiksniai, lemiantys pluoštinių linų morfogenezę dulkinių kultūroje
}

Ramunė Masiené,

Aušra Blinstrubienè,

Natalija Burbulis

Aleksandro Stulginskio universitetas, Studentu g. 11,

LT-53361 Akademija, Kauno r.

El.paštas: ausra.blinstrubiene@asu.lt
Sëjamasis linas (Linum usitatissimum L.) - lininiu šeimos augalas, svarbus ne tik aliejaus, bet ir pluošto gamybai. Linų selekcija ir šiomis dienomis yra ilgas bei sudetingas procesas, besiremiantis tarpveisline hibridizacija ir geriausių augalų atranka, todèl genetiškai stabilių linijų kūrimas užtrunka ilgą laiką - 10-12 metų. Tik sparčios selekcijos technologijos gali padèti sukurti naujas veisles, vertingas vietinei pramonei, kurios atvertų šiam augalui naują rinką. Tačiau ne visada augalų regeneracija būna efektyvi, todèl labai svarbu atrinkti genotipus, gebančius formuoti organogenines struktūras in vitro sistemoje. Genotipas ir augimo reguliatorių derinys indukcijos terpëje - vieni svarbiausių veiksnių, lemiančių kaliaus organogeninę diferenciaciją dulkinių kultūroje, todèl optimalios auginimo sąlygos turi būti parenkamos kiekvienam konkrečiam genotipui. Tirtas maitinamosios terpès sudèties poveikis penkių pluoštinių linų veislių ląstelių dediferenciacijai ir antrinei diferenciacijai izoliuotų dulkinių kultūroje. Nustatyta, kad veislių 'Sartai' ir 'Vaižgantas' izoliuotos dulkinès intensyviausiai pridètinius pumpurus regeneracijos terpèje formavo auginant jas indukcijos terpèje su didesniu auksinu nei citokininų kiekiu. Tačiau veislès 'Snaigiai' antrinè diferenciacija intensyviau vyko indukavus kalių maitinamojoje terpëje su didesniu citokininų nei auksinų kiekiu. Padidintas sacharozės kiekis indukcijos terpejje skatina organogeninių genotipų pridètinių pumpurų susiformavimo dažnį.

Raktažodžiai: augimo reguliatoriai, dulkinių kultūra, genotipas, Linum usitatissimum $\mathrm{L}$.

\section{IVADAS}

Linum gentis priskiriama seniausiai auginamiems augalams, o sejjamasis linas (Linum usitatissimum L.) - vienas pirmųjų žinomų augalų žmonijos istorijoje (Spence et al., 2003; Jankauskienè, Bačelis, 2009). Linai naudojami ne tik maisto pramoneje, bet ir gyvulių pašarui, taip pat šis augalas jau tūkstančius metų naudojamas medicinoje dẻl unikalių sėmenų aliejaus sudedamųjų dalių - nepakeičiamų a-linoleno ( $\Omega$-3) ir linolo ( $\Omega$-6) rūgščių (Abbadi et al., 2004; Karg, 2011).

Pluoštinių linų selekcija klasikiniais selekcijos metodais Lietuvoje vykdoma nuo $1922 \mathrm{~m}$. (Jankauskienè, Bačelis, 2009). Mokslininkai siūlo sutrumpinti selekcinio darbo procesą naudojant izoliuotų dulkinių kultūros metodą, kurio sèkmè priklauso nuo daugelio veiksnių, pvz., motininio augalo genotipo (Chen, Dribnenki, 2002; Obert et al., 2004; Burbulis, Blinstrubienè, 2011), žiedadulkių išsivystymo stadijos ir donorinio augalo auginimo sąlygų (Pretova, Obert, 2000; Chen, Dribnenki, 2002), maitinamosios terpès sudèties (Rutkowska-Krause et al., 2003; Obert et al., 2004; Burbulis, Blinstrubiené, 2011). Dulkinių kultūroje dažniausiai vyksta netiesiogine androgenezè - iš pradžių susidaro nediferencijuotas kalius, iš jo vèliau regeneruojami augalai (Nichterlein et al., 1991; Chen et al., 1998a). Pagrindinè problema linų dulkinių kultūroje - santykinai nedidelis 
kaliaus bei pridètinių pumpurų formavimosi dažnis (Nichterlein et al., 1991; Chen et al., 1998b). Siekiant pagerinti augalų regeneratų išeigą svarbiausi yra du aspektai: 1) atrinkti genotipus, gebančius formuoti struktūras; 2) sudaryti tinkamiausias auginimo sąlygas atrinktų genotipų regeneracijai.

Darbo tikslas - nustatyti augimo reguliatoriu derinių ir sacharozés koncentracijos indukcijos terpejje poveiki pluoštinių linų veislių kaliaus indukcijai bei ūglių regeneracijai izoliuotų dulkinių kultūroje.

\section{METODAI IR SĄLYGOS}

Tyrimai atlikti Aleksandro Stulginskio universiteto Agrobiotechnologijos laboratorijoje. Tirtos penkios pluoštinių linų veislès: 'Belinka', 'Dangiai', 'Sartai,' 'Snaigiai,' 'Vaižgantas'. Sèklos daigintos auginimo kameroje kontroliuojamomis sąlygomis: 16 val. fotoperiodas, $18 / 14{ }^{\circ} \mathrm{C}$ temperatūra (dieną / naktį), 75 \% drègnumas. Augalai auginti durpių, kompostinès žemès ir smèlio mišinyje, santykiu $3: 1: 2,16,5 \mathrm{~cm}$ skersmens induose. Augimo metu augalai tręšti $(\mathrm{N}: \mathrm{P}: \mathrm{K})$ santykiu $20: 20: 20$.

Donorinių augalų žiedpumpuriai išoriškai sterilinti $70 \%$ etanolio vandeniniame tirpale $1 \mathrm{~min}$. ir $2 \%$ natrio hypochlorite - $10 \mathrm{~min}$., po to 3 kartus perplauti steriliu distiliuotu vandeniu. Sterilūs eksplantai auginti plastikinèse Petri lèkštelèse, talpinančiose $15 \mathrm{ml}$ NLN indukcijos terpès (Lichter, 1985) su skirtingais citokininų ir auksinų deriniais (2 $\mathrm{mg} \mathrm{l}^{-1}$ 6-benzilaminopurino (BAP) $+1 \mathrm{mg} \mathrm{l}^{-1} 1$-naftilacto rūgšties (NAR), $1 \mathrm{mg} \mathrm{l}^{-1}$ 6-benzilaminopurino (BAP) $+2 \mathrm{mg} \mathrm{l}^{-1}$ 3-indolilacto rūgšties (IAR), $1 \mathrm{mg} \mathrm{l}^{-1}$ 6-bezilaminopurino (BAP) + 0,5 $\mathrm{mg} \mathrm{l}^{-1} 3$-indolilacto rūgšties $(\mathrm{IAR})+0,5 \mathrm{mg} \mathrm{l}^{-1} 1$-naftilacto rūgšties (NAR)), $6 \%$ arba $9 \%$ sacharozés bei $0,6 \%$ agaro koncentracijomis. Izoliuotos dulkinès augintos $25^{\circ} \mathrm{C}$ temperatūroje tamsoje 28 dienas, po to kas keturias savaites kultūra perkelta ị šviežią maitinamąją terpę ir auginta kontroliuojamomis sąlygomis: 16 val. fotoperiodas, $22 \pm 2{ }^{\circ} \mathrm{C}$ temperatūra (dieną / naktị), šviesos intensyvumas $-50 \mu \mathrm{mol} \mathrm{m} \mathrm{m}^{-2} \mathrm{~s}^{-1}$.

Üglių regeneracijai kalius perkeltas į $\mathrm{MS}(\mathrm{Mu}-$ rashige, Skoog, 1962) maitinamają terpę, papildytą $1 \mathrm{mg} \mathrm{l}^{-1}$ BAP, $375 \mathrm{mg} \mathrm{l}^{-1}$ glutaminu, $3 \%$ sacharozès ir $0,6 \%$ agaro koncentracijomis.

Visuose eksperimentuose naudota pilna rendomizacija. Auginta po 120 kiekvieno varianto dulkinių (10 dulkinių / Petri lèkštelèje; 12 pakartojimu / variante) ir kiekvienas eksperimentas atliktas tris kartus. Po keturių savaičių nustatytas kaliaus susidarymo dažnis (\%) ((kalių formavusių eksplantų skaičius / eksplantų skaičius lèkštelèje) $\times 100 \%)$. Üglių susidarymo dažnis (\%) nustatomas po kiekvieno kultūros perkèlimo ant šviežios maitinamosios terpès. Duomenys statistiškai apdoroti kompiuterinemis programomis STAT 1,55 ir ANOVA iš programų paketo SELEKCIJA (Tarakanovas, Raudonius, 2003).

\section{REZULTATAI IR JŲ APTARIMAS}

Linų androgenezès procesas glaudžiai susijęs su kaliaus tarpsniu, nes izoliuotų dulkinių kultūroje linai dažniausiai regeneruoja netiesiogiai - iš nediferencijuotų kaliaus ląstelių (Nichterlein et al., 1991; Chen et al., 1998a). Norint užtikrinti morfogeninio kaliaus formavimąsi būtina sudaryti optimalias sąlygas izoliuotų dulkinių auginimui in vitro.

Rezultatai, gauti tiriant augimo reguliatorių derinių ir sacharozès koncentracijos poveiki linų kaliaus indukcijai izoliuotų dulkinių kultūroje, pateikti 1 pav. Genotipų 'Sartai' ir 'Snaigiai' dulkinès intensyviausiai kalių formavo maitinamojoje terpeje, papildytoje $2 \mathrm{mg} \mathrm{l}^{-1} \mathrm{BAP}$ ir $1 \mathrm{mg} \mathrm{l}^{-1} \mathrm{NAR}$, o $1 \mathrm{mg} \mathrm{l}^{-1}$ BAP ir $2 \mathrm{mg} \mathrm{l}^{-1}$ IAR derinys skatino veisliu 'Belinka', 'Dangiai' ir 'Vaižgantas' izoliuotų dulkinių kaliaus genezę.

Padidintas sacharozès kiekis indukcijos terpèje skatino veislių 'Sartai,' 'Snaigiai' ir 'Vaižgantas' kaliaus genezę, tačiau inhibavo veislių 'Belinka' ir 'Dangiai' kaliaus susiformavimo dažnį.

Üglių regeneracija - linų androgenezès proceso kritinis periodas. Iš tirtų penkių pluoštinių linų genotipuc, pridetinius pumpurus formavo tik triju genotipų kalius. Priklausomai nuo indukcijos terpès sudeties, pumpurų formavimosi dažnis regeneracijos terpèje varijavo nuo 4,5\% ('Snaigiai') iki $24 \%$ ('Sartai') (2 pav.). Intensyviausiai pridètinius pumpurus formavo veislių 'Sartai' ir 'Vaižgantas' izoliuotų dulkinių kalius, indukuotas terpeje su $1 \mathrm{mg} \mathrm{l}^{-1} \mathrm{BAP}$ ir $2 \mathrm{mg} \mathrm{l}^{-1} \mathrm{IAR}$. Augimo reguliatoriu derinys $2 \mathrm{mg} \mathrm{l}^{-1} \mathrm{BAP}$ ir $1 \mathrm{mg} \mathrm{l}^{-1}$ NAR indukcijos terpèje skatino veislès 'Snaigiai' pumpurų susiformavimą regeneracijos terpeje. Padidintas (9 \%) sacharozès kiekis indukcijos terpeje skatino visų trijų veislių antrinę diferenciaciją. 


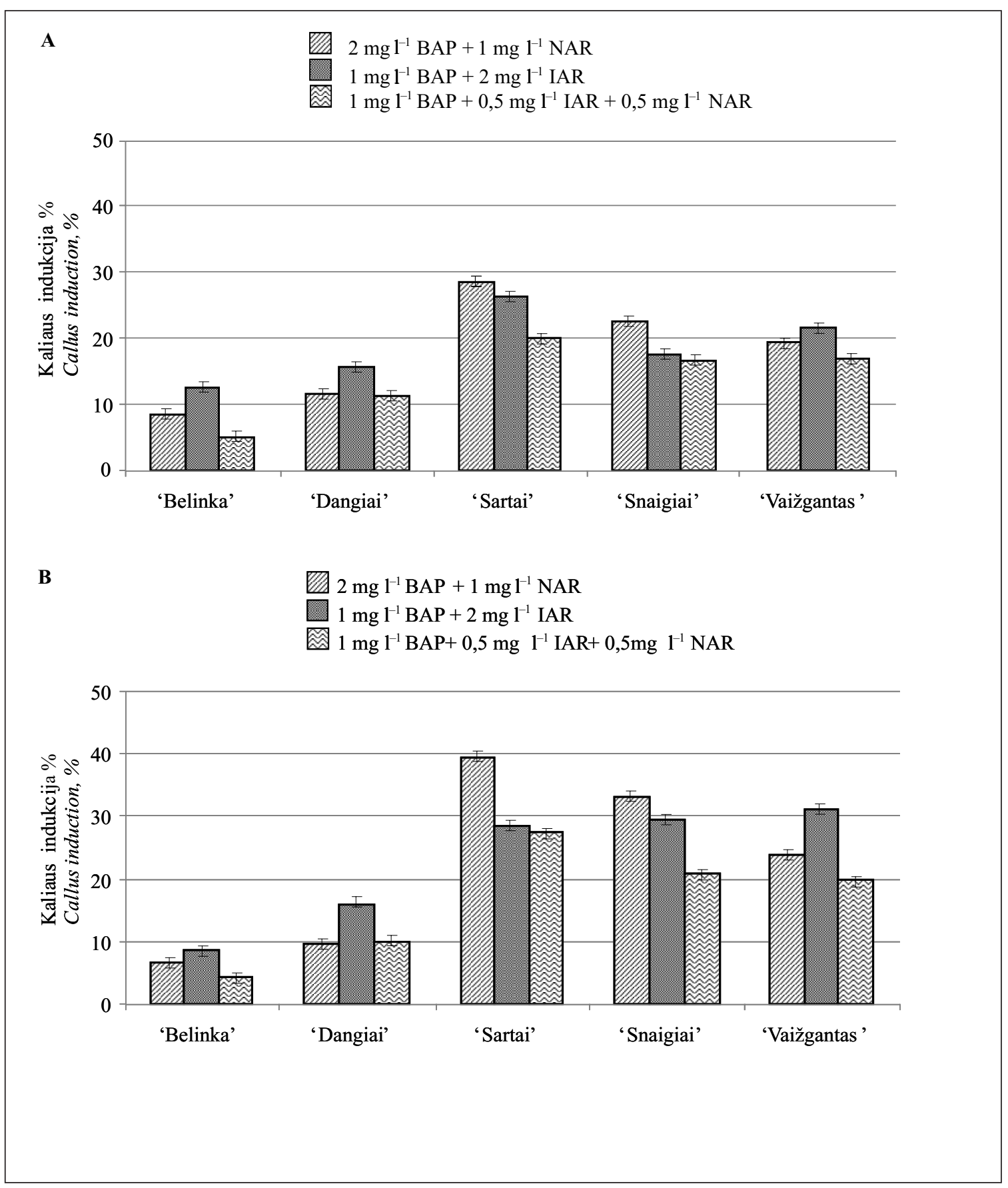

1 pav. Augimo reguliatorių ir sacharozės koncentracijos ịtaka pluoštinių linų kaliaus indukcijai dulkinių kultūroje: A - $6 \%$ sacharozės; B - $9 \%$ sacharozès

Fig. 1. Effect of growth regulators and sucrose concentration on callus induction in anther culture of fibre flax: $A-6 \%$ sucrose; $B-9 \%$ sucrose

Geba formuoti kaliu gali skirtis ne tik tarp atskirų augalo rūšių, bet ir tos pačios rūšies viduje (Chen, Dribnenki, 2002; Burbulis, Blinstrubienè, 2011). Daugelis mokslininkų nustatè, kad kaliaus indukcijai tiek generatyvinių ląstelių (Rutkowska-Krause et al., 2003; Obert et al., 2004; Burbulis et al., 2005), tiek somatinių audinių (Rutkowska-Krause et al., 2003;
Salaj et al., 2005; Yildiz, Ozgen, 2006; Burbulis et al., 2012) kultūrose svarbią reikšmę turi donorinio augalo genotipas. Mūsų tyrimais nustatyta, kad iš tirtų pluoštinių linų veislių didžiausia morfogenine galia pasižymèjo veislès 'Sartai' izoliuotos dulkinès.

Kitas svarbus veiksnys, lemiantis kaliaus indukciją ir augalų regeneraciją - maitinamosios 


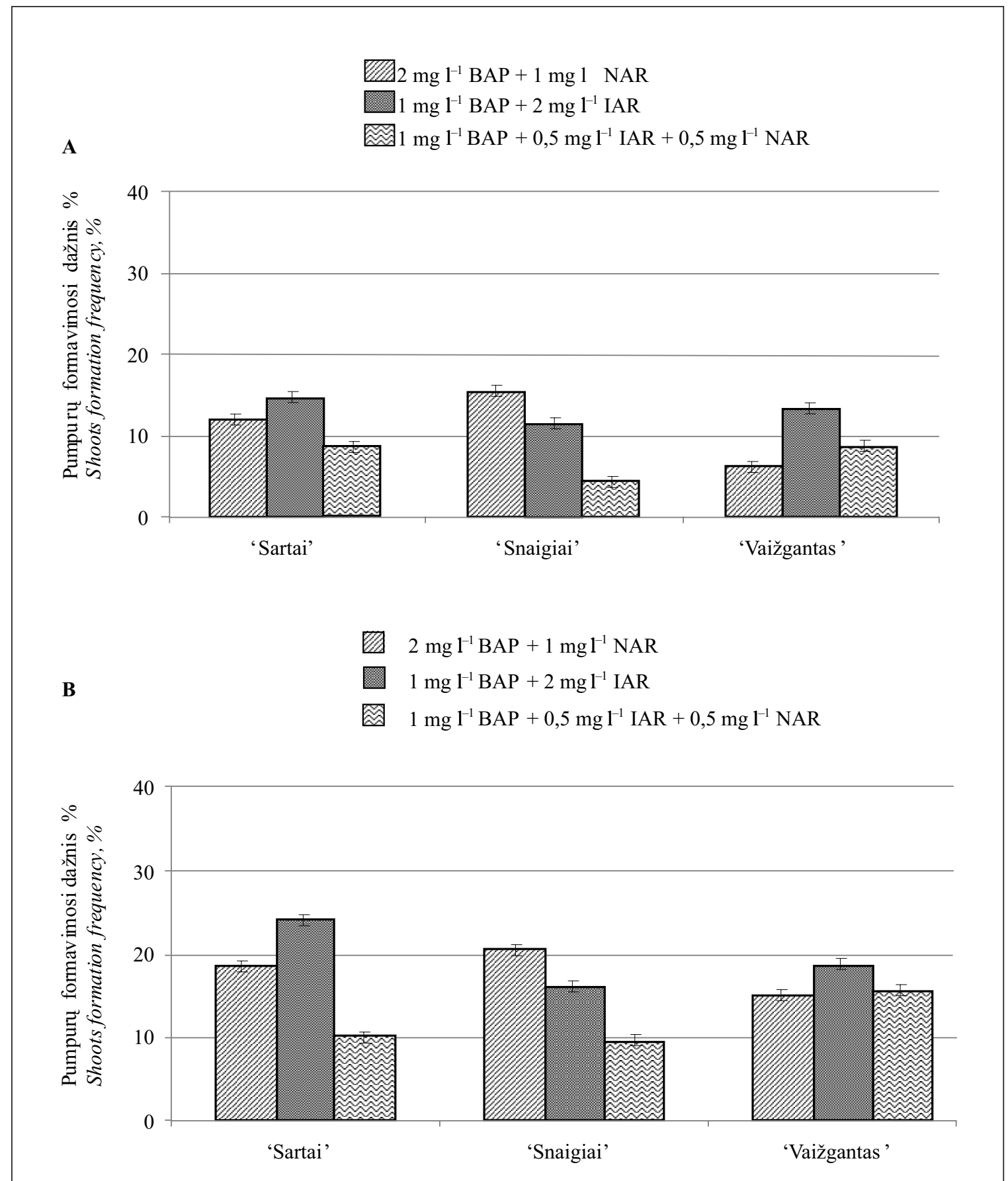

2 pav. Augimo reguliatorių ir sacharozės koncentracijos indukcijos terpèje ịtaka pluoštinių linų pumpurų formavimuisi regeneracijos terpèje: A - $6 \%$ sacharozės; B - $9 \%$ sacharozės

Fig. 2. Effect of growth regulators and sucrose concentration in the induction medium on buds formation in the regeneration medium of fibre flax: $A-6 \%$ sucrose; $B-9 \%$ sucrose

terpès sudètis. Y. Chen su bendraautoriais (1998b) nustatè, kad linų kaliaus genezè intensyviausiai vyko terpeje, papildytoje augimo reguliatorių deriniu $1 \mathrm{mg} \mathrm{l}^{-1}$ BAP ir $2 \mathrm{mg} \mathrm{l}^{-1} 2,4 \mathrm{D}$, o E. Tejklovos (1996) tyrimuose linų dulkinių dediferenciaciją labiau skatino $2 \mathrm{mg} \mathrm{l}^{-1} \mathrm{BAP}$ ir $1 \mathrm{mg} \mathrm{l}^{-1} \mathrm{NAR}$. Mūsu tyrimais nustatyta, kad derinys $2 \mathrm{mg} \mathrm{l}^{-1} \mathrm{BAP}$ ir
$1 \mathrm{mg} \mathrm{l}^{-1}$ NAR skatina tik veislès 'Snaigiai' androgenezès procesą, o veislių 'Sartai' ir 'Vaižgantas' didžiausias pridètinių pumpurų formavimosi dažnis, gautas veikiant derinio $1 \mathrm{mg} \mathrm{l}^{-1}$ BAP ir $2 \mathrm{mg} \mathrm{l}^{-1}$ IAR. Tai patvirtina kitų mokslininkų teiginí, kad optimalus augimo reguliatorių derinys maitinamojoje terpèje turi būti parenkamas kiekvienam 
genotipui individualiai (Nichterlein et al., 1991; Chen, Dribnenki, 2002; Rutkowska-Krause et al., 2003; Lasaga et al., 2004; Obert et al., 2004).

Kaip angliavandenių šaltinis izoliuotų audinių kultūrose dažniausiai naudojama sacharozè, kurios optimali koncentracija androgenezès indukcijai varijuoja, priklausomai nuo augalo rūšies ir genotipo (Hazarika et al., 2000; Chen, Dribnenki, 2004; Jo et al., 2009; Millam et al., 2005). Ankstesniais mūsų tyrimais nustatyta, kad padidintas sacharozès kiekis indukcijos terpeje skatina androgenezės procesą sèmeninių linų izoliuotų dulkinių kultūroje (Burbulis et al., 2005). Ivertinus šiame straipsnyje pateiktus rezultatus, nustatyta, kad didesnè sacharozès koncentracija indukcijos terpeje padidina pluoštinių linų regenerantų išeigą izoliuotų dulkinių kultūroje.

\section{IŠVADOS}

1. Pluoštinių linų gebejjimas formuoti struktūras izoliuotų dulkinių kultūroje didžiąja dalimi lemiamas genotipo reakcijos $\mathfrak{i}$ egzogeninius augimo reguliatorius, todèl optimalus auginimo reguliatorių derinys turi būti parenkamas konkrečiam genotipui.

2. Veislès 'Snaigiai' izoliuotų dulkinių auginimui indukcijos terpe turi būti papildyta deriniu $2 \mathrm{mg} \mathrm{l}^{-1}$ 6-benzilamino purino ir $1 \mathrm{mg} \mathrm{l}^{-1} 1$-naftilacto rūgšties, o veislių 'Sartai' ir 'Vaižgantas' androgenezès indukcijai labiau tinka augimo reguliatorių derinys $1 \mathrm{mg} \mathrm{l}^{-1}$ 6-benzilamino purino ir $2 \mathrm{mg} \mathrm{l}^{-1} 3$-indolilacto rūgšties.

3. $9 \%$ sacharozès koncentracija indukcijos terpejje padidina tirtų veislių produktyvių dulkinių išeigą.

Gauta 12130219

Priimta 12130424

\section{LITERATŪRA}

1. Abbadi A., Domergue F., Bauer J., et al. 2004. Biosynthesis of very-long-chain polyunsaturated fatty acids in transgenic oilseed: constraints on their accumulation. Plant Cell. Vol. 16. P. 27342748.

2. Burbulis N., Blinstrubiene A. 2011. Genotypic and exogenous factors affecting linseed (Linum usitatissimum L.) anther culture. Journal of Food, Agriculture \& Environment. Vol. 9. No. 3-4. P. 364367.
3. Burbulis N., Blinstrubienè A., Masienė R., et al. 2012. Genotypic and growth regulator effects on organogenesis from hypocotyl explants of fiber flax (Linum usitatissimum L.). Journal of Food, Agriculture \& Environment. Vol. 10. No. 1. P. 397400.

4. Burbulis N., Blinstrubienè A., Sliesaravičius A., et al. 2005. Influence of genotype, growth regulators, sucrose level and preconditioning of donor plants on flax (Linum usitatissimum L.) anther culture. Journal of Food, Agriculture \& Environment. Vol. 56. P. 323-331.

5. Chen Y., Dribnenki P. 2004. Effect of medium osmotic potential on callus induction and shoot regeneration in flax anther culture. Plant Cell Reports. Vol. 23. P. 272-276.

6. Chen Y., Dribnenki P. 2002. Effect of genotype and medium composition on flax Linum usitatissimum L. anther culture. Plant Cell Reports. Vol. 21. P. 204-207.

7. Chen Y., Kenaschuk E., Procunier J. D. 1998a. Plant regeneration from anther culture in Canadian cultivars of flax (Linum usitatissimum L.). Euphytica. Vol. 102. P. 183-189.

8. Chen Y., Kenaschuk E., Dribnenki P. 1998b. High frequency of plant regeneration from anther culture in flax, Linum usitatissimum L. Plant Breeding. Vol. 117. P. 463-467.

9. Hazarika B. N., Parthasarathy V. A., Nagaraju V., et al. 2000. Sucrose induced biochemical changes in in vitro microshoots of Citrus species. Indian Journal of Horticulture. Vol. 57. P. 27-31.

10. Yildiz M., Ozgen M. 2006. A comparison of growth regulators for adventitious shoot regeneration from hypocotyls of flax (Linum usitatissimum L.). Journal of Food, Agriculture \& Environment. Vol. 4. No. 3-4. P. 171-174.

11. Jankauskienė Z., Bačelis K. 2009. Naujų pluoštinių linų veislių 'Dangiai', 'Snaigiai' ir 'Sartai' sukūrimas bei tyrimai. Žemés ūkio mokslai. Nr. 1-2. P. 31-40.

12. Jo E. A., Tewari R. K., Hahn E. J., et al. 2009. In vitro sucrose concentration affects growth and acclimatization of Alocasia amazonica plantlets. Plant Cell, Tissue and Organ Culture. Vol. 96. P. 307-315.

13. Karg S. 2011. New research on the cultural history of the useful plant Linum usitatissimum L. (flax), a resource for food and textiles for 8,000 years. Vegetation History and Archaeobotany. Vol. 20. P. 507-508.

14. Lasaga S. L., Camadro E. L., Bonell M. L., et al. 2004. Diallel analysis of callus formation ability in linseed anther culture. Plant Breeding. Vol. 123. P. 502-504.

15. Lichter R. 1985. From microspores to rape plants: a tentative way to low glucosinolate strains. World Crops: Production, Utilization, Description. Vol. 11. P. 268-277. 
16. Millam S., Obert B., Pretova A. 2005. Plant cell and biotechnology studies in Linum usitatissimum - a review. Plant Cell, Tissue and Organ Culture. Vol. 82. P. 93-103.

17. Murashige T., Skoog F. 1962. A revised medium for rapid growth and bioassays with tobacco tissue cultures. Physiologia Plantarum. Vol. 15. P. 473-497.

18. Nichterlein K., Umbach H., Friedt, W. 1991. Genotypic and exogenous factors affecting shoot regeneration from anther callus of linseed (Linum usitatissimum L.). Euphytica. Vol. 58. P. 157-164.

19. Obert B., Dedicova B., Hricova A., et al. 2004. Flax anther culture: effect of genotype, cold treatment and media. Plant Cell, Tissue and Organ Culture. Vol. 79. P. 233-238.

20. Pretova A., Obert B. 2000. Progress in flax androgenesis. In: Bohanec B. (ed.). Biotechnological Approaches for Utilization of Gametic Cells. Proceedings of the COST 824 Final Meeting. Bled, Slovenia. P. 165-169.

21. Rutkowska-Krause I., Mankowska G., Lukaszewicz M., et al. 2003. Regeneration of flax (Linum usitatissimum L.) plants from anther culture and somatic tissue with increased resistance to Fusarium oxysporum. Plant Cell Reports. Vol. 22. P. 110-116.

22. Salaj J., Petrovska B., Obert B., et al. 2005. Histological study of embryo-like structures initiated from hypocotyl segments of flax (Linum usitatissimum L.). Plant Cell Reports. Vol. 24. P. 590-595.

23. Spence J. D., Thornton T., Muir A. D., et al. 2003. The effect of flax seed cultivars with differing content of a-linolenic acid and lignans on responses to mental stress. Journal of the American College of Nutrition. Vol. 22. P. 494-501.

24. Tarakanovas P., Raudonius S. 2003. Agronominiu tyrimu statistine analize taikant kompiuterines programas ANOVA, STAT, STAT-PLOT iš paketo "Selekcija“ ir „Irristat“. Akademija, Kèdainių r. 57 p.

25. Tejklova E. 1996. Some factors affecting anther culture in Linum usitatissimum L. Rostlynna Vyroba. Vol. 42. P. 249-260.

\section{Ramunè Masienè, Aušra Blinstrubienė, Natalija Burbulis}

\section{FACTORS AFFECTING FIBRE FLAX MORPHOGENESIS IN ANTHER CULTURE}

\section{Summary}

Flax (Linum usitatissimum L.), a member of the family $L i$ naceae, is an important crop for the production of both oil and fibre. In breeding of fibre flax the conventional process of breeding sufficiently homozygous lines takes a substantial time (i. e. at least 10-12 years). Generally, the breeder uses either pedigree selection or bulk breeding methods to create novel lines. Rapid breeding techniques could accelerate the production of new fibre flax cultivars with characters that are adapted to the current demands of industry, opening new markets for this crop. However, the overall efficiency of plant regeneration is not efficient, therefore identification of responsive genotypes and improvement of protocols are the prerequisite to applied breeding programs. Genotype and growth regulators in the induction medium are very important factors preconditioning callus organogenic differentiation in anther culture, so the specific combination of growth regulators and sucrose concentration for callus induction must be designed for each genotype. The effects of induction medium compositions on five cultivars of fibre flax anther culture were investigated in order to improve the efficiency of cell dedifferentiation and secondary differentiation. Cultivar 'Sartai' and 'Vaižgantas' showed the highest shoot regeneration frequency when callus had inducted in the medium supplemented with higher amount of auxins than cytokinins while combination of higher amount of cytokinins than auxins promoted shoot formation in the anther-derived callus of 'Snaigiai'. The media supplemented with an increased level of sucrose resulted in the highest overall shoot formation frequency for all responsive genotypes.

Key words: anther culture, genotype, growth regulators, Linum usitatissimum $\mathrm{L}$. 